https://doi.org/10.4316/CC.2020.02.001

\title{
CINEMA AS A TOOL FOR INFLUENCING HISTORICAL CONSCIOUSNESS IN RUSSIAN-UKRAINIAN INFORMATION WARFARE
}

\author{
Roman KHARDEL ID, Vitalii VYZDRYK ID, Oleksandra MELNYK \\ Hetman Petro Sahaidachny National Army Academy, Lviv (Ukraine) \\ E-mail: spantamano@ukr.net,v.vyzdryk05@gmail.com,immlviv@gmail.com
}

\begin{abstract}
The article analyses the techniques and methods used to influence historical consciousness through the cinema. The strategy of using cinema in the modern information environment as a tool of psychological influence on the consciousness and subconscious of the target audience is described. Cinema is considered as an integral part of a comprehensive system of influencing the target audiences, including such an essential part of it as historical consciousness. The effectiveness of modern means of providing feedback on the watched films, particularly in the form of audience reviews, as a part of a complex strategy of information exploitation is highlighted.

The phenomenon of the interaction of prosthetic memory with the collective one while forming and consolidating the beliefs necessary for the initiator of information influence is studied. The advantages of cinema as a tool for creating prosthetic memory are given, such as imagery, the effect of presence in the events of the past, the identification of the viewer with the film characters, the simplicity of the material presentation.
\end{abstract}

Keywords: Cinema, Information warfare, historical consciousness, Russia, Ukraine, prosthetic memory.

Rezumat: Cinematografia ca instrument de influențare a conștiinței istorice în războiul informațional ruso-ucrainean. Articolul analizează tehnicile și metodele utilizate pentru a influența conștiința istorică prin intermediul cinematografiei. Este descrisă strategia utilizării cinematografiei în mediul informaţional modern ca instrument de influență psihologică asupra conștiinței și subconștientului unui grup țintă. Cinematografia este considerată parte integrantă a unui sistem cuprinzător de influențare a publicului, vizând un element esențial al acestuia, respectiv conștiința istorică. Este evidențiată eficacitatea mijloacelor moderne de a oferi o reacție la filmele vizionate, în special sub forma recenziilor din partea celor care le-au vizonat, ca segment al unei strategii complexe de exploatare a informațiilor. 
Este studiat fenomenul interacțiunii memoriei protetice cu cea colectivă, în timpul formării și consolidării credințelor necesare celui care generează influența informațională. Avantajele cinematografiei ca instrument pentru crearea memoriei protetice constau, prin intermediul imaginilor, în efectul aducerii în prezent a unor evenimente din trecut, identificarea privitorului cu personajele filmului, simplitatea prezentării producției cinematografice.

\section{INTRODUCTION}

One of the most effective modern methods of achieving political goals is information warfare. According to the Russian researcher Sergey Rastorguyev, information warfare is a struggle between states using information weapons, i.e. overt and covert purposeful information influences of systems (states) on each other to gain an advantage in the material sphere, where information influences are exerted by means, the use of which allows achieving the intended goals. ${ }^{1}$ The Russian-Ukrainian information warfare itself is a set of measures that are continuously implemented in the information space of Ukraine, Russia, as well as in the global world information space. The implementation of these measures aims to gain strategic and political advantages by demoralizing or misleading the enemy and countering the actions of the other party. ${ }^{2}$

Information warfare is a multifaceted concept and includes a significant number of complex dimensions. Martin C. Libicki - a well-known theorist of information warfare - compares the attempts to understand all aspects of the information warfare concept to the efforts of blind people to perceive an elephant: someone touches a leg and calls it a tree, someone touches a tail and calls it a rope, but to comprehend the whole nature of this phenomenon is extremely difficult. ${ }^{3}$

One of the components of information warfare is information expansion. According to the Russian researcher Andrey Manoylo, it represents "activities to achieve national interests by conflict-free penetration into the information sphere to make gradual, planned and invisible to the societal changes in the system of

${ }^{1}$ С. П. Расторгуев, Философия информационной войны [Philisophy of information warfare], Москва, Московский психолого-социальный институт, 2003, с. 123.

2 See: Olexander Lysenko, Svetlana Pavlovskaya, Valerii Hrytsiuk, The Soviet Special Propaganda in the Second World War. Target: the Romanian Army, in "Codrul Cosminului, XXV, 2019, No. 2, pp. 341-368.

${ }^{3}$ Martin C. Libicki, What is Information Warfare?, Washington, National Defense University, 1995, p. 3-4. 
social relations modelled on the source of expansion; wiping out the national ideology and the national value system and replacing them with own values and ideological guidelines; increasing the degree of influence and presence, exercising control over strategic information resources, information and telecommunication structure as well as national mass media; increasing the presence of own media in the information sphere of the object of penetration, etc."4

Under such conditions, defining the objects of information confrontation becomes very important. An object of information confrontation is considered any item in relation to which it is possible to exert information influence, resulting in the modification of its properties as an information system. Accordingly, an object of information confrontation can be the following segments of information and psychological space:

- the collective and individual consciousness of citizens;

- socio-political systems and processes;

- information infrastructure;

- information and psychological resources.

The psychological resources include the following components of the information space:

- the system of values of society;

- psychological tolerance of the value system (stability of the value system concerning external or internal destructive influences);

- individual and collective (public) consciousness of citizens;

- psychological tolerance of citizens' consciousness (resistance of consciousness to manipulative influence and involvement in illegal activities);

- mental health of citizens;

- mental health tolerance of citizens (resilience of mental health to external and internal destructive influences). ${ }^{5}$

An essential component of both collective and individual consciousness of citizens is the historical consciousness, which is, according to the Russian researcher Zhan Toshchenko, a set of ideas, views, beliefs, feelings and attitudes that reflect the perception and evaluation of the past in all its diversity and it is

${ }^{4}$ А. В. Манойло, А. И. Петренко, Д. П. Фролов, Государственная информационная политика в условиях информационно-психологической войны [State Information Policy in conditions of Information and Psychological Warfare], Москва, Горячая линия-Телеком, 2009, с. 75.

${ }^{5}$ А. В. Манойло, Государственная информационная политика в особых условиях. Монография [State information policy under special cirumstances. Monograph], Москва, МИФИ, 2003, с. 280. 
inherent in the society as a whole, in various socio-demographic, socioprofessional and ethno-social groups, as well as individuals. ${ }^{6}$

From the standpoint of sociology, Yuriy Levada considers that historical consciousness encompasses all the variety of forms that have developed spontaneously or have been formed by science, in which the society recognizes (perceives and evaluates) its past - or rather, in which society reproduces its movement in time. ${ }^{7}$ The essence of historical consciousness is the collection, accumulation, storage and daily use of historical knowledge gained through theoretical analysis and from the experience of practical life in the past for reproducing the ancestral life of the human community. In other words, historical knowledge is needed by the current generation to take a step forward on its basis. Historical consciousness is a mechanism that comprehensively rethinks the events of the past and conveys historical knowledge in the right perspective for the present. ${ }^{8}$ Historical knowledge can be transmitted in various ways; now, it is done through learning or under the media's influence. Given the possibility of influencing the process of disseminating such knowledge through the media, the enemy gets the opportunity to adjust society's development in a favourable direction.

Accordingly, one of the most effective methods of achieving specific goals in such a confrontation is using the pre-planned, comprehensive, and variable impact on such an element of social consciousness as historical consciousness. A widely used tool to implement this informational influence method on historical consciousness through the media is the cinema in all its modern manifestations. Thus, the analysis of manipulation of historical consciousness as an object of information confrontation, including the cinema, is one of the priority tasks facing the modern academic community.

The issues of cinema influence on the public consciousness, including such an integral part of it as historical consciousness, are widely studied by the Ukrainian academic community, particularly in the works by Heorhiy

${ }^{6}$ Ж. Т. Тощенко, Историческое сознание и историческая память: анализ современного состояния [Historical consciousness and historical memory: analysis of the contemporary state], in "Новая и новейшая история", 2000, №. 4 , с. 3.

${ }^{7}$ Ю. А. Левада, Историческое сознание и научный метод [Historical consciousness and scientific method], in Философские проблемы исторической науки [Philosophical problems of historical science], Москва: Наука, 1969, с. 186-225.

${ }^{8}$ В. М. Вашкевич, Історична свідомість студентської молоді: ціннісно-світоглядні орієнтири. Навчальний посібник [Historical consciousness of student youth: values and worldviews. Tutorial], Київ, Світогляд, 2010, с. 31. 
Pocheptsov, ${ }^{9}$ Larysa Bryukhovets'ka, ${ }^{10}$ Serhiy Bezklubenko, ${ }^{11}$ Mykyta Katsuba. ${ }^{12}$ The problem of the cinema influence on collective memory is studied in the research by Ol'ha Hontars'ka. ${ }^{13}$ These topics are also analysed in the works of such Russian authors as Galina Prozhiko, ${ }^{14}$ Aleksandr Fiodorov, ${ }^{15}$ Kiril Razlogov. ${ }^{16}$ Among the foreign researchers are John E. O'Connor, ${ }^{17}$ Alison Landsberg18 and Marc Ferro. ${ }^{19}$ However, certain features of the use of the cinema as part of a comprehensive strategy of information warfare, in combination with other media, which in particular, can exert influence on the historical consciousness of the target audiences, requires more detailed analysis.

\section{MODERN FILMS AS MEANS OF INFLUENCE ON HISTORICAL CONSCIOUSNESS}

Vast opportunities for contemporary consumers of audiovisual products (viewers) to choose materials for viewing have significantly changed the direction

${ }^{9}$ Г. Г. Почепцов, Bid Facebook'y i гламуру до Wikileaks: медіа-комунікації [From Facebook and glamor to Wikileaks: Media Communication], Київ, Спадщина, 2014.

10 Л. І. Брюховецька, Найцікавіша історія в Європі. Екранні версії [The most interesting history in Europe. Screen versions], Київ, Задруга, 2014.

${ }^{11}$ С. Д. Безклубенко, Кіномистецтво та політика [Cinema and Politics], Київ, 1995.

12 М. О. Кацуба, Художнє кіно як засіб формування масової політичної свідомості [Art cinema as means of shaping mass political consciousness], in "Політичний менеджмент", 2013, No. 1-2, p. 136-144.

13 О. Гонтарська, Історичне кіно в дослідженнях пам'яті в Україні часів трансформації [Historical Cinema in Memory Studies during Ukraine Transformation], in Iсторичні і політологічні дослідження. Спеціальний випуск, Вінниця, 2018, с. 97-102.

${ }^{14}$ Г. С. Прожико, Концепция реальности в экранном документе [The concept of reality in a screen document], Москва, ВГИК, 2004.

15 А. В. Фёдоров, Трансформации образа России на западном экране: от эпохи идеологической конфронтации (1946-1991) до современного этапа (1992-2015) [Transformations of Russia's image on Western screen: from the era of ideological confrontation (1946-1991) to the modern stage (1992-2015)], Москва, Информация для всех, 2015.

${ }^{16}$ К. Э. Разлогов, Мировое кино: история искусства экрана [World cinema: history of screen art], Москва, Эксмо, 2015.

${ }^{17}$ John O'Connor, Image as Artifact. The Historical Analysis of Film and Television, Melbourne, Robert E. Krieger Publishing Co., 1990.

18 Alison Landsberg, Prosthetic memory. The Transformation of American Remembrance in the Age of Mass Culture, New York, Columbia University Press, 2004.

19 Marc Ferro, Cinema and history, Detroit, Wayne State University Press, 1988. 
vector of information influence using the potential of film production. The viewer can choose specific content from a massive amount of the available material, which is precise to their taste and does not conflict with previously formed beliefs. Until very recently, the Soviet audience, including in Ukraine, viewed only films available to them. In other words, the ones that were censored and sufficiently consistent with the government's information policy. Otherwise stated, if previously the cinema was able to form beliefs, then in modern conditions, the film production mainly deepens and reinforces beliefs which have already been created - and in this field, contemporary cinema is a potent tool.

The audience's ability to give feedback on the viewed movies also gains pronounced importance in current conditions. Recently the viewer had an opportunity to comment on the viewed pictures only in personal communication with acquaintances, to read the official (in the vast majority - pro-government) reviews, which specified what and how the visual material should be understood. Nowadays, the possibilities of feedback are much more significant, and anyone has an opportunity to comment on any product (even on films that have not been watched) - from a simple statement "liked - disliked" to detailed reviews describing their own experiences, opinions, conclusions. And the modern viewer en masse reads reviews and feedback on the selected movie before watching it, which determines, firstly, the choice of the film to watch, and secondly, lays the foundation for a mental response to the content of the film. In fact, in some cases, the conclusion is ready before watching; all that remains is to "approve" it at a conscious level. The process of compiling reviews of film products in the Russian Federation is organized and adjusted by the apparatus that plans and carries out the information warfare, including that with Ukraine.

When talking about cinema, as a tool to influence historical consciousness, the phenomenon of "prosthetic memory" described by Alison Landsberg is widely used. ${ }^{20}$ This type of memory does not coincide, and sometimes contradicts the collective memory (public memory), when the audiovisuals from the first-person perspective (through the eyes of the characters of the film, with which the viewer involuntarily identifies) communicates a specific view of past events, following the plan of film producers. Faced with a conflict of memory types, the viewer tries to eliminate the internal dissonance and adjust their collective memory attitude. Such transformation sequences alter (slowly but inevitably) the conditional image of collective memory in a necessary direction for the movie sponsors.

Therefore, the question raised by the historical cinema researcher Robert

${ }^{20}$ Alison Landsberg, Prosthetic memory..., p. 2. 
A. Rosenstone becomes hugely relevant: "Does a Filmic Writing of History exist (...) meaning the process by which we transform the remains of the past into what we call History?"21 Rosenstone himself cannot give an unequivocal answer to such a complicated question, primarily because of the ambiguity of the perception of the term "history" in the modern world. However, if we interpret history as "prosthetic memory" that gradually transforms "public memory" (and through this transformation inevitably creates the historical consciousness of a specific target audience required by the sponsors), the answer will be quite positive. Rosenstone cites the prophetic words of the American director and founder of cinema as an art, David Wark Griffith, as an argument: "The time will come when children in public schools will be taught almost everything, with the help of moving images. Surely they will not have to reread the story. To learn about Napoleon, people would not have to wade laboriously through a host of books, and ending up bewildered, confused at every point by conflicting opinions about what did happen".22 The new environment - Rosenstone argues - will change what we mean when we use the word "history". The world in which we see the past, in which we see stories, live them, attach our emotions to people and evoke long-ago events. Perhaps in such a world, factual details are less important than the emotion of immediacy, identification with our predecessors - all-powerful elements, kinaesthetic feeling, or even knowledge?23

\section{IMAGE OF UKRAINE AND UKRAINIANS IN RUSSIAN FILMS}

Under a scrupulous analysis, the map of emotional imprinting (fixation in the mind of signs of objects to form stereotypes of "their behaviour"), which is applied using film products, is similar to the one used against the Ukrainian people by Russian information machine employing other means. We think that the pattern applied to Ukraine and history of Ukrainians by Russian propaganda can be formulated as follows: every Ukrainians' attempts to realize their strategy on the historical development and state formation are inevitably inept, inhumane and dangerous in the perspective of civilization. Simultaneously, in most squares,

${ }^{21}$ Robert Rosenstone, Reflections on what the historical filmmaker does (to history), in Jennie M. Carlsten, Fearghal McGarry (eds), Film, history and memory, London, Palgrave Macmillan, 2015, p. 184-185.

${ }^{22}$ Melvyn Stokes, D. W. Griffith's The Birth of a Nation. A History of "The Most Controversial Motion Picture of All Time", New York, Oxford University Press, 2008, p. 8.

${ }^{23}$ Robert Rosenstone, Reflections on what..., p. 186. 
in the background, the picture of a typical Ukrainian is created and consolidated. This picture is almost indistinguishable from the one that was successfully developed in Russian literature over a century ago. In an open letter to Russian writers, Volodymyr Vynnychenko describes it as follows: "a little stupid, somewhat crafty, certainly lazy, melancholic, and sometimes kind-hearted. ... Whatever the figure, it is either a clumsy fool, or a stupid, lazy person, or a lazy rascal. It is very seldom a short-sighted, sentimental, good-natured dupe like Maxim Gorky's khokhol."24 With a correction to the modern worldview, the image of a Ukrainian, by and large, is translated as follows: "A Ukrainian is a so-called wrong Russian: either funny, or disgusting, or dangerous". For example, Russian political scientist Andrey Okara said: "In Soviet times, a Ukrainian was a joyful, cheerful, somewhat limited "khokhol" in films, a kind of a colourful character albeit not the main hero. If before it could be an army sergeant, or a representative of the grassroots, now in the movies "White Guard", TV series "Autonomka", movies "Match", "We are from the future-2", "Brother-2", "Admiral" the image of a Ukrainian is not a cool funny khokhol, but a vicious collaborator and a traitor".25

The Austrian researcher Andreas Kappeler describes the Russian society's attitude to Ukrainians as follows: "The position of Ukrainians in the Russian state's socio-political system in the 19th century was ambiguous. The tsarist government and Russian society thought of them as khokhols, Little Russians, or Mazepites. Ukrainian peasants, who continued to live in the traditional Ukrainian-speaking world, remained friendly, submissive, and colourful in their dances and songs, but generally uncultured, stupid Ukrainians. [...] Most Russians still see Ukrainians as Little Russians, part of the Russian nation, and do not understand why Ukrainians are trying to maintain their language, culture, and state. Despite urbanization and industrialization, Ukrainians are still considered to be underdeveloped peasant people, the khokhols. However, linguistic, cultural and historical proximity has led to the fact that there are almost no ethnic antagonisms between Russians and Ukrainians. True 'friendship of peoples' is possible only when the Russians recognize the Ukrainians as an equal nation."26

The extreme form of Russians' attitude towards Ukrainians is demonstrated

\footnotetext{
${ }^{24}$ В. К. Винниченко, Открытое письмо русским писателям [An open letter to Russian writers], in “Украинская жизнь”, 1913, Vol. 10, p. 29-30.

25 Росбалт. Политолог: Образ украинца в российском кино меняется, in https://www.rosbalt.ru/ukraina/2012/04/17/970677.html/ [Accessed on 20.12.2019].

26 Ibid.
} 
by the LDPR faction leader in the State Duma of the Russian Federation Vladimir Zhirinovsky, speaking on one of the television shows: "Ukraine - there is no such country, and there are no such people. We will execute them."27

As we can see, in a hundred years, only the technical means have changed, but the mental maps and templates that are communicated by them have remained virtually unchanged.

A typical example of the history of Ukraine as seen in Russia was the film "Project Ukraine", shown on the channel "Russia 24". The authors of the script were Andrey Medvedev and Tat'yana Salomadina, and the director was Vitaliy Maksimov. The film was shot by the All-Russia State Television and Radio Broadcasting Company with the financial support of the Federal Agency for Press and Mass Communications of Russia, i.e. by order and at the expense of the Russian government. The category of the film in the annotations is defined as "documentary". This film is a collection of characteristic ideologues, the main of which is Ukrainian statehood's artificiality. Accordingly, it is continuously emphasized that in the late Middle Ages and early modern times, the concept of Ukraine did not exist. The Moscophile political movement that really existed in the Ukrainian lands, which were part of the Austro-Hungarian monarchy, was suppressed by the Ukrainophilia movement artificially created by the Austrians to counter Polish and Russian influence.

At the same time, modern Ukraine is allegedly strongly influenced by Western Ukrainian ideas, as well as Galician ideology, which has little in common with the mentality of the inhabitants of Central Ukraine, and even more so the East and South of the country. Thus, Ukrainian statehood appears on the one hand as an artificial project. On the other hand, it seems feasible, but only in alliance with Russia, without which it will be a derivative of Galician nationalism, which poses a clear threat to Russia and Ukraine itself. The film contains propaganda clichés such as "Ukrainians are an artificially created nation," or "the Ukraine project was created to harm Great Russia." 28

27 Е. Клименко, Нет такой страны и такого народа: Жириновский пригрозил расстрелом всех украинцев [There is no such country and there is no such nation. Zhirinovsky threats to shoot all of the Ukrainians], in https://replyua.net/putin/ 68756-net-takoy-strany-i-takogo-naroda-zhirinovskiy-prigrozil-rasstrelom-vsehukraincev.html (Accessed on 29.01.2020).

${ }_{28}$ А. В. Гущин, Образ Украины в современных Российских СМИ и публицистике в контексте Российско-Украинского кризиса [The image of Ukraine in modern Russian media and journalism in the context of the Russian-Ukrainian crisis], in http://regional-dialogue.com/ru/image-of-ukraine (Accessed on 21.12. 2019). 
One of the typical manipulative techniques used in the film "Project Ukraine" is an expert's use as an authority. For example, the film uses excerpts from an interview with the world-famous Polish film director, screenwriter, and producer Krzysztof Zanussi, who enjoys considerable public prestige in Poland and Ukraine. Krzysztof Zanussi expresses moderate and well-founded ideas, mainly about Ukrainian-Polish relations. At the same time, other little-known experts involved in the film, introduced as scientists, historians, political scientists, offer the viewer rather dubious, and in some cases completely unacceptable conclusions: "Nobody knows where the term 'Ukrainian lands' came from. Today this term is so widely used, so popular around the globe, fascinated by the idea of Ukrainian people, Great Ukraine, which has never actually existed"29 (Szczepan Siekierka, leader of the Wrocław Association for the Commemoration of the Victims of the Crimes of Ukrainian Nationalists /Poland/). "In the Tsardom of Muscovy, the Orthodox lived freely"30 (Andrey Marchukov, a senior researcher at the Institute of Russian History of the Russian Academy of Sciences). "In 1654, the Pereyaslav Rada was signed (as in the movie text), a document on unification a part of Western Rus including Kiev and the territories of the Zaporozhian Host whit the Moscow state [...] Historians knew perfectly well that the state of Ukraine in 1654 did not exist. These territories were called Little Russia." 31 Such pseudohistorical information is brought to the audience by one of the script's authors and the host of the film Andrey Medvedev.

"Ukrainian separatism has grown into a civil war, which we are now witnessing"32 - informs the audience Pavel Kuzenkov, associate professor of history at Moscow State University. The term "separatism" in this quote is applied to an independent state's policy, and the aggression of the Russian Federation against Ukraine recognized by international institutions (the UN General Assembly, the Parliamentary Assembly of the Council of Europe) is called a civil war. Pavel Kuzenkov, who was mentioned earlier, states the following33: "So far it has been a fratricidal war. We also bear our share of guilt, and this guilt is primarily ideological. We did not deal with this issue at all. We let everything go. We thought that only through the pipeline (obviously, gas supply to Ukraine), we would control the

\footnotetext{
${ }^{29}$ Виталий Максимов (режисер), Проект “Украина" [Vitaliy Maksimov (Director), Project “Ukraine”], Москва, ВГТРК, 2014, time: 05:35 - 06:02.

${ }^{30}$ Ibid., time: 13:47 - 13:53.

${ }^{31}$ Ibid., time: 14:42 - 14:55 and 15:08 - 15:18.

32 Ibid., time: 1:25:15 - 1:25:21.

${ }^{33}$ Ibid., time: 1:26:02 - 1:26:20.
} 
whole situation. This is an extremely profound mistake". In his view, the mistake is the lack of control over an independent state and independent people.

Another typical example of cinema's use as a means of information confrontation is the documentary film "Crimea. The way Home". Sergey Kraus directed the film, the author and host of the film was the Russian journalist Andrey Kondrashov. The film premiered on 15 March 2015, on the channel "Russia 1". According to the Russian research company TNS Gallup Media, it demonstrated a too high interest of the Russian viewers. By January 2020, the YouTube version had garnered more than 13 million views, and the video was classified as "Unacceptable or Offensive to Some Audiences". The film was a nominee in the category "TV Event of the Season" at the 19th annual TEFI awards, and won a special jury prize "For the Comprehension of Contemporary History". However, the IMDb international rating of the film is extremely low: 2.8 out of 10 . The documentary covers the preparation and implementation process of the Crimean Peninsula annexation by the Russian Federation and the implementation of "secret evacuation" of President Viktor Yanukovych by Russian secret services. A significant part of the plot represents the interview with Russian President Vladimir Putin, in which he states that he led the action to seize Crimea. Notably, one can observe changes in the Russian President's position on the events in Crimea: on 4 March 2014, he claimed that it wasn't the Russian military who took part in the operations, but "local self-defence forces". On 17 April 2014, he said that the Russian military "were behind the self-defence forces", whereas on 13 November he told about the blockade of Ukrainian military units by Russian servicemen. ${ }^{34}$ In the film, the President of the Russian Federation calls Russia's actions in Crimea a "special operation", and talks about a covert survey of Crimean residents carried out by representatives of his administration, about the readiness to use nuclear weapons in the event of third party intervention. The film's primary purpose is to demonstrate to the Russian audience the power of Russia and to the world audience - the readiness to transgress any norms for the sake of imperial ambitions.

The film "Crimea. The Way Home" transmits some Russian propaganda myths, especially one of the so-called "Korsun Incident". Eyewitnesses and participants of the events allegedly claim that dozens of Crimean Anti-Maidan activists returning home from Kyiv on 20 February 2014, were stopped and killed

${ }^{34}$ А.Синицын, Владимир Путин обозначил новый этап и уровень самоизоляции России [Vladimir Putin outlined a new stage and self-isolation level of Russia], in https://www.vedomosti.ru/newspaper/articles/2015/03/16/ot-redaktsii-putinidet-na-rodinu (Accessed on 28.01.2020). 
at a checkpoint near Korsun-Shevchenkivskyi, in Cherkasy Oblast, Ukraine. Although the authors of the film refer to the data provided allegedly by the Ministry of Internal Affairs of Ukraine about seven dead and more than 20 missings, no human deaths were confirmed, and no names of those killed or missing in the events were published. In February 2014, the Office of the Ministry of Internal Affairs of Ukraine in Cherkasy Oblast and the Main Directorate of the Ministry of Internal Affairs of Ukraine in Crimea denied information about the dead and missing. ${ }^{35}$ Besides, talking about this incident, the authors of the film do not mention the three hostages in one of the buses - residents with traces of physical violence, one of them with a knife wound, who were taken hostage at a previous checkpoint in the village of Myronivka. ${ }^{36}$ Russian President Vladimir Putin cites the case as an example of an "outbreak of extreme nationalism", a proof of a threat to Crimean residents and a reason for "not leaving them in the lurch".

It is necessary to emphasize that such a technique as "Shuffle Tracking" or "accentuation" means one-sided selection and conscious presentation of only positive or negative facts with the simultaneous omission of the opposites ones. ${ }^{37}$ Thus, in the Russian films, the plot of which (in one way or another) covers the activities of the Hilfspolizei (Auxiliary Police in the Third Reich during the Second World War in the occupied territories), the employees of such organizations are mostly Ukrainians, regardless of the location. Simultaneously, in films, their national or pseudo-national differences (usually language, clothing) are often hypertrophied. The material selected and presented in this way creates a conviction in the viewer: most police collaborators were Ukrainians, and the Russians were not involved in their crimes. Therefore, Ukrainians (as a nation) are associated with an openly negative phenomenon: the collaboration with the Nazis in the occupied territories. Moreover, the type of such a police officer selected in most cases is frankly negative.

35 Ошибки в фильме "Крым. Путь на родину" [Mistakes in the film "Crimea. The Way Home"], in https://www.stopfake.org/ru/oshibki-v-filme-krym-put-na-rodinu (Accessed on 28.01.2020).

36 Д. Д. Бунякіна, Черкащани: “Корсунський погром" - вигадка російських пропагандистів" [Cherkashchany: "Korsun's Incident" is a hoax of Russian propagandists], in https://www.radiosvoboda.org/a/26904323.html (Accessed on 28.01.2020).

37 Г. В. Грачев, И. К. Мельник, Манипулирование личностью: организация, способы и технологии информационно-психологического воздействия [Personality manipulation: organization, methods and technologies of information and psychological impact], Москва, Алгоритм, 2002, p. 84. 
The most typical example is the film "Match", a historical drama produced in 2012, written by Tymofey Sergeytsev, Igor' Sosna and Dmitriy Zver'kov, and directed by Andrey Maliukov (since September 2014 the film has been banned from showing in Ukraine as propaganda). One of the police collaborators' roles in this film is played by the People's Artist of Ukraine Ostap Stupka. The actor himself explains his role in the anti-Ukrainian film as follows: "I honestly played the characters I was offered. Artistically I was interested in such heroes because there are scoundrels and scums in every nation. But then I did not feel that I was being used in anti-Ukrainian propaganda. This was out of the question. Besides, it was unwise to sit and wait until Ukrainian films were made because every artist is greedy for work." 38 Indeed, each nation has its own negative and positive images, but the trick of shuffle tracking is to choose this image among all and reproduce it as much as possible. When asked by the journalist why he wore a blue-and-yellow band on his sleeve in the film, since the policemen did not wear them, Ostap Stupka answered that he did not care who wore what at that time. ${ }^{39}$ Ukrainian politician and Verkhovna Rada deputy Andriy Parubiy describes the film as follows: "It is a kind of propaganda of the Russian world, where all these things are at the background. The main thing is to show that if a person is wearing a Ukrainian embroidered shirt, he or she is a collaborator. The film shows that if there's a Ukrainian flag and the people speak the Ukrainian language, they must be the Nazis' aides. My opinion is that this film incites ethnic hatred."40

\section{UKRAINIAN COUNTERMEASURES TO INFORMATION INFLUENCE OF RUSSIAN FEDERATION IN FILMS}

When developing a strategy to counter information influence in the field of the cinema, it is necessary to take into consideration the fact that cinema as a means of persuasion is a component in the more extensive complex system, which envisages synchronous work of all elements involved - online sources, media,

38 Л. Фесенко, Остап Ступка, актор театру і кіно [Ostap Stupka, the actor of theater and cinema], in https://www.ukrinform.ua/rubric-culture/1963956-ostap-stupkaaktor-teatru-i-kino.html (Accessed on 21.12.2019).

${ }^{39}$ Синдром Юди [Judas Syndrome], in https://ktm.ukma.edu.ua/show content.php?id=1369 (Accessed on 21.12.2019).

40 Парубий: фильм "Матч" - это пропаганда русского мира [Parubiy: the film "Match" is propaganda of the Russian world], in https://www.obozrevatel.com/politics/ 74350-parubij-film-match-eto-propaganda-russkogo-mira.htm (Accessed on 21.12.2019). 
television and more. Accordingly, the strategy to counter such influences must consider appropriate measures agreed in time, content and direction to neutralize information attacks in all related areas.

If we consider the activities mentioned above of the Russian Federation against Ukraine in the field of cinema as information and psychological influence, i.e. organized targeted intervention in the consciousness (subconsciousness) of the target audience; obviously, the need arises for information counteraction, which is a purposeful information process carried out by one side as an adequate response to information activities against it by the other side. In this case, we are talking about counteracting information and psychological influence - targeted measures aimed at preventing information interference by social engineering methods into the consciousness (subconsciousness) of the target audience to correct its behaviour and (or) worldview, change its moral and psychological state. ${ }^{41}$

The former United State Secretary of State Hillary Rodham Clinton has described in a speech the best method of information countermeasures: "Some take the view that, to encourage tolerance, some hateful ideas must be silenced by governments. We believe that efforts to curb the content of speech rarely succeed and often become an excuse to violate freedom of expression. Instead, as it has historically been proven time and time again, the better answer to offensive speech is more speech. People can and should speak out against intolerance and hatred. By exposing ideas to debate, those with merit tend to be strengthened, while weak and false ideas tend to fade away; perhaps not instantly, but eventually. Now, this approach does not immediately discredit every hateful idea or convince every bigot to reverse his thinking. But we have determined as a society that it is far more effective than any other alternative approach."42

It is clear that in cinema as a means of influencing consciousness, the most effective strategy of counteraction is to create your own quality cinema for both Ukrainian and world viewers. At the same time, cooperation with representatives of the world film industry is also critical. It should be noted that in recent years there have been significant achievements in this area.

${ }^{41}$ Система стратегічних комунікацій держави у воєнній сфері. Терміни та визначення [The system of strategic communications of the state in the military sphere. Terms and definitions], in http://stratcom.nuou.org.ua/wp-content/ uploads/2020/01/Система-стратегічних-комунікацій-держави-у-воєнній-сфері.Терміни-та-визначення.pdf (Accessed on 06.07.2020).

42 U.S. Department of State, Internet Rights and Wrongs: Choices \& Challenges in a Networked World, in https://2009-2017.state.gov/secretary/20092013clinton/rm/ 2011/02/156619.htm (Accessed on 02.06.2020). 
Thus, in September 2018, a Ukrainian historical and biographical film "The Secret Diary of Symon Petliura" was released. It was directed by Oles' Yanchuk and written by Mykhailo Shayevych, and became was the first full-fledged film (in the years of independence), dedicated to one of the most famous and controversial Ukrainian statesmen - Symon Petlyura. The movie aims at a wide range of viewers. It can hardly be considered a documentary since the plot is based on Petlyura's fictional diary and has some historically contradictory issues. The film attempts to highlight the human qualities of the controversial political figure of the Chief Ataman of the Ukrainian People's Republic, head of the Directory and organizer of the Ukrainian Armed Forces, to reveal the heavy burden of responsibility of a politician for his actions. The authors of the film draw discernible semantic parallels with the present.

The picture received mixed reviews in Ukrainian society. Audience feedback on online resources is mostly positive. ${ }^{43}$ Most Ukrainian critics generally evaluate the work positively but point out specific problems and downsides in this form of presenting historical material. For example, Ol'ha Petrenko-Tseunova concludes her review as follows: "In general, Oles' Yanchuk's film is definitely worth watching and not just to support the Ukrainian producer. However, to avoid disappointment, we should bear in mind that the 'Secret Diary of Symon Petlyura' says much more about the present than about the events of a century ago. It shows that history has not yet been lived or talked through." 44 At the same time, there are frankly negative comments from Ukrainian critics who, characteristically, are mostly Russian-speaking. Thus, Dariya Bad'or, the editor of the "Culture" section of the "Left Bank" online resource called her review: Shameful movie: what's wrong with the 'Secret Diary of Symon Petlyura'. The film is described as follows: "Yanchuk's film fully corresponds to his current nomenclature biography - it is so full of Soviet clichés with stale air and loud slogans about how to love the homeland." 45 In another similar review by Mykola Mylinevs'kyy on the Internet

43 Фильм "Тайный дневник Симона Петлюры" [Film "The Secret Diary of Simon Petlyura"], in https://kino-teatr.ua/film/tamniy-schodennik-simona-petlyuri49568.phtml (Accessed on 21.01.2020).

${ }^{44}$ О. Петренко-Цеунова, “Таємний аккаунт Симона Петлюри": минуле й сьогодення в художньо-історичному творі ["The Secret Diary of Symon Petlyura": the Past and the Present in historical fiction], in http://litakcent.com/2018/09/17/tayemniy-akkauntsimona-petlyuri-minule-y-sogodennya-v-hudozhno-istorichnomu-tvori/ (Accessed on 21.01.2020).

45 Д. Бадьор, Стыдное кино: что не так с "Тайным дневником Симона Петлюры" [Shameful movie: what's wrong with "The Secret Diary of Simon Petlyura"], in 
portal "Vesti.ua" the following opinion was expressed: "The film was shot as if it was the $70^{\text {th }}$ (of the $20^{\text {th }}$ century - author's note) - and it's about one of the Bolsheviks, who faltered, but was true to the idea, and in the history of the country, he justifiably took a worthy place." 46 The "Secret Diary of Symon Petliura" was not shown in Russia and did not create a corresponding resonance in Russian society.

Another landmark premiere in Ukrainian cinema is the film "Forbidden", which covers the life and mysterious death of the famous poet of the sixties, human rights activist, Hero of Ukraine - Vasyl' Stus and his struggle against the Soviet system. The film was directed by Roman Brovko and written by Serhiy Dzyuba and Artemiy Kirsanov. The original titles of the movie "Bird of the Soul" and "Stus" were changed into "Forbidden". According to the State Agency of Ukraine for Cinema, the decision to leave out the poet's name belonged to the creative team that considered the film as a biography of a particular person, as an image of time, and a personification of the struggle against the regime. ${ }^{47}$

The film's production is connected with a loud scandal in Ukrainian society regarding the exclusion from the script of a court scene featuring a well-known Ukrainian politician, former Head of the Presidential Administration of Ukraine Viktor Medvedchuk, who acted as a lawyer in the Stus trial. According to Ukrainian lawyers Roman Tytykalo and Illa Kostin: "Actually, defender Medvedchuk became an accomplice to the prosecution, acting contrary to the rule of law and the requirements of professional ethics... Confirming the guilt of his client in court (when the defendant himself denied the guilt), lawyer Medvedchuk compromised his professional duty, in reality, refused to defend Stus, which grossly violated the latter's right to defence in court."48 It is noteworthy that Viktor Medvedchuk played a similar role in other dissidents' trials - Yuriy Lytvyn and Mykola Kuntsevych.

https://lb.ua/culture/2018/09/11/407259_stidnoe_kino_taynim.html (Accessed on 21.01.2020).

${ }^{46}$ Н. Милиневский, Смерть Петлюры, которой трудно дождаться - рецензия на новый украинский фильм [The death of Petlyura, which is hard to wait for - a review of a new Ukrainian film], in https://vesti.ua/kultura/302099-smert-petljury-kotorojtrudno-dozhdatsja-retsenzija-na-novyj-ukrainskij-film (Accessed on 21.01.2020).

47 Фільм про Стуса вийде в прокат під назвою “Заборонений” - Держкіно [A film about Stus will be released under the title "Forbidden" - Ukrainian State Film Agency], in https://ua.interfax.com.ua/news/general/560811.html (Accessed on 21.01.2020).

48 P. С. Титикало, І. П. Костін, Стус без шансу на захист: ведмежа послуга Медведчука [Stus without a chance for defense: Medvedchuk's disservice], in https://www.pravda.com.ua/cdn/graphics/2016/08/stus/ (Accessed on 21.01.2020). 
Actor Henadiy Popenko allegedly announced that the court scene was taken out from the script at the request of Viktor Medvedchuk himself, later this information was also confirmed by the film's producer Artem Denysov. Still, he stressed that the scene disappeared from the script due to the film's timeline. When this information was disclosed, it caused a significant resonance among Ukrainian society both in social networks and media. Later on, the then Prime Minister of Ukraine Volodymyr Hroysman stated that the Ministry of Culture and the State Agency for Cinema should check whether the Ukrainian poet's life story and Soviet dissident Vasyl' Stus in the feature film was accurate. ${ }^{49}$ Apparently, as a result, the scene with the lawyer did appear in the movie, but the lawyer's name was not mentioned. Medvedchuk himself commented on the public response to the coverage of his role in the Stus case in the program "A Great Interview with a Great Politician" on the 112 Ukraine TV channel: "This is a provocation. One of the stages of what Americans are doing today. We have proof of that. I mean, they are constantly provoking. [...] this is another provocation, which, unfortunately, has a place today. And we will get over it too. In the case of Stus, which was 38 years ago, I am glad that in 38 years the Americans have not found anything new. The story is distorted."50

The film "Forbidden" has received mixed reviews from Ukrainian critics. Among a significant number of positive reviews, there are also negative ones, a considerable part of which are again from the Russian-speaking audience. For example, the feedback of the already mentioned Daria Badior entitled "Forbidden": a film about Vasyl' Stus, not worthy of his hero. ${ }^{51}$ The main negative points mentioned in the reviews are the excessive amount of chronicles used in the movie, poor directing and acting, unnaturalness, stereotypical staging in general. Instead, the viewers' feedback is almost entirely positive. The film's audience rating on the Ukrainian portal Kino-Teatr.ua is 9.0 out of 10 , and as of January 2020, it ranks

${ }^{49}$ С. Середа, Скандал навколо фільму про Стуса: сцену з Медведчуком повернуть [Scandal surrounding the movie about Stus: Medvedchuk's scene will be returned], in https://www.radiosvoboda.org/a/29427655.html (Accessed on 21.01.2020).

50 Медведчук назвав історію з фільмом про Василя Стуса "провокацією американців"

[Medvedchuk calls the story of the film about Vasil Stus a "provocation by the Americans"], in https://detector.media/infospace/article/140468/2018-08-26medvedchuk-nazvav-istoriyu-z-filmom-pro-vasilya-stusa-provokatsieyuamerikantsiv/ (Accessed on 21.01.2020).

51 Д.Бадьор, “Заборонений”: фильм про Василя Стуса, недостойный своего героя [Forbidden: the film about Vasil Stus is not worthy of his hero], in https://lb.ua/culture/2019/09/06/436622_zaboroneniy_film_pro_vasilya.html (Accessed on 21.01.2020). 
4 th in the overall rating of all movies on the portal. The IMDB world rating is also relatively high -7.2 , which indicates that Ukrainian historical cinema can be popular both in Ukraine and in the world.

The history of Ukraine has also been a source for the world film industry. For example, in February 2019, at the 69th Berlin International Film Festival, Polish director Agnieszka Holland's film "The Price of Truth", written by Andrea Halupa and starring Jason Norton and Vanessa Kirby, won the Golden Bear Award. In English, the film was shown under the title "Mr. Jones". The movie tells the story of British journalist Gareth Jones, who was one of the first to publish in the world press the information about the mass famine in Ukraine in 1932-1933 and its causes - forcible seizure of food from peasants, the policy of collectivization and dekulakization. An illustrative example of the feedback is the comment of one of the viewers on the IMDb website entitled "Who said that we care more about the truth than 90 years ago? No, we don't care", which contains the following conclusion: "Sure, many will insist that all the horrible stuff the movie is about is firmly in the past, but I am afraid we are born to repeat history and this tragic story in particular. At least some can tell the truth whatever consequences. Watch it, and you will have your answer."52

In October 2019, a joint Ukrainian-American historical feature film "Zakhar Berkut" directed by Akhtem Seitablayev and John Wine starring Robert Patrick was released. This picture is a film adaptation of the historical novel with the same name "Zakhar Berkut" by Ivan Franko. Director Akhtem Seitablayev, with the Ukrainian State Film Agency's support, has started shooting the iconic film "The Battle of Konotop".

In the genre of the documentary film, it is worth mentioning such works as "Maidan" and "Process" directed by Serhiy Loznytsya and highly praised by both Ukrainian and world critics; "Volunteers of the God's Ranks" directed by Serhiy Loznytsya and Leonid Kanter; "Ilovays'k. Knights of Heaven" and "Pisky. Knights of Heaven" led by Kateryna Strel'chenko. It is worth noting the project "Documentary", in which director Taras Khymych made several documentary films: "Golden September: The Galician Chronicles 1939-1941", "Silver Land: The Chronicles of Carpatho-Ukraine 1919-1939", "The Ukrainian Insurgent Army: Chronicles 1942-1945", and "Legion. Chronicle of Ukrainian Galician Army 19181919". These films differ from the typical examples of Ukrainian documentaries due to the "Discovery" format, which involves modern perspectives and technical

${ }^{52}$ Who said we care more about the truth now than 90 years ago? No, we do not, in https://www.imdb.com/review/rw5293495/?ref_=tt_urv (Accessed on 21.01.2020). 
means during the shooting process, making the film close to a feature film. The movies rely on archival documents, materials and eyewitness memoirs. The mentioned films are freely accessible on the Documentary Project website, and the premieres were shown free of charge at the Kinopalats cinema in Lviv. ${ }^{53}$

\section{CONCLUSION}

The vast opportunities offered by the cinema as a means of influencing the collective consciousness can be used, and are being used by the Russian Federation in the information war against Ukraine. One of the critical areas of influence is historical consciousness as an integral part of Russian and Ukrainian peoples' public consciousness. At the same time, the use of cinema, as any other modern weapon, is effective only in combination with other available means within the framework of a carefully planned flexible strategy, which provides for adjustment of the influence taking into account the feedback received during the use of all involved tools.

Thus, modern cinema as a source of audiovisual media is an essential tool used in modern information warfare to create prosthetic memory, which, in turn, gradually transforms the public memory in the direction necessary for the initiator of conscious influence. Simultaneously, the effective use of cinema as a means of information warfare, including the impact on historical consciousness, is possible only in a comprehensive strategy engaging all modern mass media on that front.

\section{BIBLIOGRAPHY:}

1. Ferro Marc, Cinema and history, Detroit, Wayne State University Press, 1988.

2. Landsberg Alison, Prosthetic memory. The Transformation of American Remembrance in the Age of Mass Culture, New York, Columbia University Press, 2004.

3. Libicki Martin, What is Information Warfare?, Washington, National Defense University, 1995.

4. Lysenko Olexander, Pavlovskaya Svetlana, Hrytsiuk Valerii, The Soviet Special Propaganda in the Second World War. Target: the Romanian Army, in "Codrul Cosminului, XXV, 2019, No. 2, pp. 341-368.

5. O'Connor John, Image as Artifact. The Historical Analysis of Film and Television, Melbourne, Robert E. Krieger Publishing Co., 1990.

${ }^{53}$ Документалістика [Documentary], in http://www.documentary.org.ua (Accessed on 21.01.2020). 
6. Rosenstone A. Robert, Reflections on what the historical filmmaker does (to history), in Carlsten M. Jennie, McGarry Fearghal (eds), Film, history and memory, London, Palgrave Macmillan, 2015, p. 183-197.

7. Stokes Melvyn, D. W. Griffith's The Birth of a Nation. A History of "The Most Controversial Motion Picture of All Time", New York, Oxford University Press, 2008.

8. U. S. Department of State, Internet Rights and Wrongs: Choices \& Challenges in a Networked World, in https://2009-2017.state.gov/secretary/20092013clinton/rm/ 2011/02/156619.htm

9. Who said we care more about the truth now than 90 years ago? No, we do not, in https://www.imdb.com/review/rw5293495/?ref_=tt_urv

10. Бадьор Д., “Заборонений”: фильм про Василя Стуса, недостойный своего героя [Forbidden:d the film about Vasil Stus is not worthy of his hero], in https://lb.ua/culture/2019/09/06/436622_zaboroneniy_film_pro_vasilya.html

11. Бадьор Д., Стыдное кино: что не так с "Тайным дневником Симона Петлюры" [Shameful movie: what's wrong with "The Secret Diary of Symon Petlyura"], in https://lb.ua/culture/2018/09/11/407259_stidnoe_kino_taynim.html

12. Безклубенко С. Д., Кіномистецтво та політика [Cinema and Politics], Київ, 1995.

13. Брюховецька Л. І., Найцікавіша історія в Європі. Екранні версії [The most interesting history in Europe. Screen versions], Київ, Задруга, 2014.

14. Бунякіна Д. Д., Черкащани: “Корсунський погром" - вигадка російських пропагандистів [Cherkashchany: "Korsun's Incident" is a hoax of Russian propagandists], in https://www.radiosvoboda.org/a/26904323.html

15. Вашкевич В. М., Історична свідомість студентської молоді: ціннісносвітоглядні орієнтири. Навчальний посібник [Historical consciousness of student youth: values and worldviews. Tutorial], Київ, Світогляд, 2010.

16. Винниченко В. К., Открытое письмо русским писателям [An open letter to Russian writers], in “Украинская жизнь”, 1913, Vol. 10, с. 29-30.

17. Гонтарська О., Історичне кіно в дослідженнях пам'яті в Украӥні часів трансформації [Historical Cinema in Memory Studies during Ukraine Transformation], in “Історичні і політологічні дослідження. Спеціальний випуск”, Вінниця, 2018, с. 97-102.

18. Грачев Г. В., Мельник И. К., Манипулирование личностью: организация, способы и технологии информационно-психологического воздействия [Personality manipulation: organization, methods and technologies of information and psychological impact], Москва, Алгоритм, 2002.

19. Гущин А. В., Образ Украины в современных Российских СМИ и публицистике в контексте Российско-Украинского кризиса [The image of Ukraine in modern Russian media and journalism in the context of the Russian-Ukrainian crisis], in http://regionaldialogue.com/ru/image-of-ukraine

20. Документалістика [Documentary], in http://www.documentary.org.ua

21. Каппелер Андреас, Мазепинцы, малороссы, хохлы: украинцы в этнической иерархии Российской империи [Mazepites, Small Russians, and Khokhols: Ukrainians in 
the Ethnic Hierarchy of the Russian Empire], in Россия - Украина: история взаимоотношений, Москва, Школа “Языки русской культуры”, 1997.

22. Кацуба М. О., Художнє кіно як засіб формування масової політичної свідомості [Art cinema as means of shaping mass political consciousness], in "Політичний менеджмент", 2013, Vol. 1-2, с. 136-144.

23. Клименко Е., Нет такой страны и такого народа: Жириновский пригрозил расстрелом всех украинцев [There is no such country and there is no such nation. Zhirinovsky threats to shoot all of the Ukrainians], in https://replyua.net/putin/68756-nettakoy-strany-i-takogo-naroda-zhirinovskiy-prigrozil-rasstrelom-vseh-ukraincev.html

24. Левада Ю. А., Историческое сознание и научный метод [Historical Consciousness and the Scientific Method], in Философские проблемы исторической науки [Philosophical problems of historical science], Москва, Наука, 1969, с. 186-225.

25. Максимов Виталий (режисер), Проект “Украина" [Project “Ukraine”], Москва, ВГТРК, 2014.

26. Манойло А. В., Государственная информационная политика в особых условиях. Монография [State information policy under special cirumstances. Monograph], Москва, МИФИ, 2003.

27. Манойло А. В., Петренко А. И., Фролов Д. П., Государственная информационная политика в условиях информационно-психологической войны [State Information Policy in conditions of Information and Psychological Warfare], Москва, Горячая линияТелеком, 2009.

28. Медведчук назвав історію з фільмом про Василя Стуса "провокацією американців" [Medvedchuk calls the story of the film about Vasil Stus a "provocation by the Americans"], in https://detector.media/infospace/article/140468/2018-08-26medvedchuk-nazvav-istoriyu-z-filmom-pro-vasilya-stusa-provokatsieyu-amerikantsiv/

29. Милиневский Н., Смерть Петлюры, которой трудно дождаться - рецензия на новый украинский фильм [The death of Petlyura, which is hard to wait for - a review of a new Ukrainian film], in https://vesti.ua/kultura/302099-smert-petljury-kotorojtrudno-dozhdatsja-retsenzija-na-novyj-ukrainskij-film

30. Ошибки в фильме "Крым. Путь на родину" [Mistakes in the film "Crimea. The Way Home"], in https://www.stopfake.org/ru/oshibki-v-filme-krym-put-na-rodinu

31. Парубий: фильм "Матч" - это пропаганда русского мира [Parubiy: the film "Match" is propaganda of the Russian world], in https://www.obozrevatel.com/politics/ 74350-parubij-film-match-eto-propaganda-russkogo-mira.htm

32. Петренко-Цеунова О., "Таємний аккаунт Симона Петлюри": минуле й сьогодення в художньо-історичному творі ["The Secret Diary of Symon Petlyura": the Past and the Present in historical fiction], in http://litakcent.com/2018/09/17/tayemniyakkaunt-simona-petlyuri-minule-y-sogodennya-v-hudozhno-istorichnomu-tvori/

33. Политолог: Образ украинца в российском кино меняется [The image of a Ukrainian in Russian cinema is changing], in https://www.rosbalt.ru/ukraina/2012/04/ 17/970677.html 
34. Почепцов Г. Г., Bid Facebook'y і гламуру до Wikileaks: медіа-комунікації [From Facebook and glamor to Wikileaks: Media Communication], Київ, Спадщина, 2014.

35. Прожико Г. С., Концепция реальности в экранном документе [The concept of reality in a screen document], Москва, ВГИК, 2004.

36. Разлогов К.Э., Мировое кино: история искусства экрана [World cinema: history of screen art], Москва, Эксмо, 2015.

37. Расторгуев С. П., Философия информационной войны [Philisophy of information warfare], Москва, Московский психолого-социальный институт, 2003.

38. Середа С., Скандал навколо фільму про Стуса: сцену з Медведчуком повернуть [Scandal surrounding the movie about Stus: Medvedchuk's scene will be returned], in https://www.radiosvoboda.org/a/29427655.html

39. Синдром Юди [Judas Syndrome], in https://ktm.ukma.edu.ua/show_ content.php?id=1369

40. Синицын А., Владимир Путин обозначил новый этап и уровень самоизоляции России [Vladimir Putin outlined a new stage and self-isolation level of Russia], in https://www.vedomosti.ru/newspaper/articles/2015/03/16/ot-redaktsii-putin-idetna-rodinu

41. Система стратегічних комунікацій держави у воєнній сфері. Терміни та визначення [The system of strategic communications of the state in the military sphere. Terms and definitions], in http://stratcom.nuou.org.ua/wp-content/uploads/2020/01/ Система-стратегічних-комунікацій-держави-у-воєнній-сфері.-Терміни-тавизначення.pdf

42. Титикало Р. С., Костін І. П, Стус без шансу на захист: ведмежа послуга Медведчука [Stus without a chance for defense: Medvedchuk's disservice], in https://www.pravda.com.ua/cdn/graphics/2016/08/stus/

43. Тощенко Ж. Т., Историческое сознание и историческая память: анализ современного состояния [Historical consciousness and historical memory: analysis of the contemporary state], in “Новая и новейшая история”, 2000, № 4 , с. 3-14.

44. Федоров А. В., Трансформации образа России на западном экране: от эпохи идеологической конфронтации (1946-1991) до современного этапа (1992-2015) [Transformations of Russia's image on Western screen: from the era of ideological confrontation (1946-1991) to the modern stage (1992-2015)], Москва, Информация для всех, 2015.

45. Фесенко Л., Остап Ступка, актор театру і кіно [Ostap Stupka, the actor of theater and cinema], in https://www.ukrinform.ua/rubric-culture/1963956-ostap-stupkaaktor-teatru-i-kino.html

46. Фильм "Тайный дневник Симона Петлюры" [Film "The Secret Diary of Symon Petlyura"], in https://kino-teatr.ua/film/tamniy-schodennik-simona-petlyuri-49568.phtml

47. Фільм про Стуса вийде в прокат під назвою “Заборонений” - Держкіно [A film about Stus will be released under the title "Forbidden" - Ukrainian State Film Agency], in https://ua.interfax.com.ua/news/general/560811.html 